\title{
Exploring Potential Visitor and Visitor Perception of Destination Image of Palabuhan Ratu Through Personal Values
}

\author{
Mohamad Robbith Subandi \\ Lecturer, Travel Department \\ Sekolah Tinggi Pariwisata Bandung \\ Bandung, Indonesia \\ E-mail: $\underline{\text { mrt@stp-bandung.ac.id }}$
}

\begin{abstract}
Purpose - The main purpose of this research is to investigate the effect of personal values on potential visitor and visitor perception of Palabuhan Ratu destination image Methodology - An extensive literature review was carried out to identify factors that influence destination image and to identify suitable instrument to measures destination image and personal values. Primary research was conducted using questionnaire as instrument for data collection, sample size was $(n=154)$ and most of them were students and alumni of Sekolah Tinggi Pariwisata Bandung chosen through non-random sampling technique, the collected data were then analyzed using regression and univariate analysis of variance in SPSS. Findings - The key finding of this research were personal values are significantly affect destination image, it was also found out that there was no significant difference of image between potential visitor and visitor of Palabuhan Ratu. Significant differences of perception also not exist across demographic segments. Subsequently several recommendations were developed for the tourism managements and authorities of Palabuhan Ratu based on research findings. Values - This study contributes to the body of knowledge by providing empirical data on the effect of personal value towards destination image perception, especially in tourism context
\end{abstract}

Keywords—Destination Image; Personal Values; List of Values (LOV), Behavior

\section{INTRODUCTION}

Tourist destination image is considered as important factor in attracting visitors, although it is largely subjective (1) the perceptions towards the destination; instead of the reality is the basis of any tourist decision or behavior (2). Therefore, the development of tourist destination image is crucial to make the destination stand out from the competitor and subsequently has a better chance to be chosen by the consumer or tourist (1). Considering the importance of destination image, many destinations want to improve their image; however as image is very subjective (3) it is very difficult to create or improved the destination image without understanding the consumer or tourist first. Nowadays traditional demographic and socio-economic factors are no longer adequate to predict tourist attitude and behavior. Subsequently a new variables should be developed and used to predict tourist attitude and behavior, one of them is personal values which has been used widely used by researcher to study behavioral phenomena (4) it also has long considered as a better predictor of human behavior than socio-demographic variables (5) furthermore (6) contended that values are part of personal factor which form the destination image. However, the actual correlation between personal values and perception of destination image, and whether personal values significantly influence perception of destination image has received a limited academic interest before, hence a study examining the effect of personal value on perception of destination image is considered suitable research.

The aim of this research is to study the extent of personal values effect on the perception of visitor and potential visitor of Palabuhan Ratu. Moreover, this research also focused on the following specific objectives:

1. From a literature review, identify the factors that influence destination image and appropriate measuring instrument for Personal Values and Destination Image.

2. To analyze the potential visitor and visitor perceptions of Palabuhan Ratu image as tourist destination

3. To evaluate the personal value of potential visitor and visitor of Palabuhan Ratu

4. To analyze whether personal values significantly affect the perception of visitor and potential visitor of Palabuhan Ratu

\section{LITERATURE REVIEW}

1. Personal Values

Research on Personal values has attracted considerable attention from researchers; they studied 
personal values and its application in several social science domains (7) some of them are; values and organic food consumer (5), Personal Values and Moviegoers (8), etc. Apparently, the reason behind this is that values significantly affect perceptions (9), attitude and behavior (10) thus many studies argued that it could be a powerful tool to predict consumer behavior (5). What makes values so effective as a consumer behavior predictive tool is because values are tend to be restricted in number, remain constant over time and function as a basis for human conduct (11) hence it can be used in various context in social science.

\section{Rokeach (12) describe value as}

"An enduring belief that a specific mode of conduct or end-state of existence is personally or socially preferable to an opposite or converse mode of conduct or end state of existence "

While other (13) describe value as

"The guidelines of life, the regulations between individuals or between individuals and society ".

In the long-term values will provide effective explanation of consumer behavior (13). Values can be divided based on its accordance; Instrumental value and terminal value are two types of values with the former are about desirable modes of conduct and the later concerning the desirable end state of existence. (12). Terminal values can also be described as representation of individual or social objectives for examples freedom or world peace. In the other hand, Instrumental values are representation of ways of being or doing things such as loyalty and honesty (8). In short, Terminal values describe what you desire from life while Instrumental values are ways of achieving those objectives or desire.

\subsection{Personal Values Measurement}

There are some instruments and methods which can be used to measure personal values, $(10,12)$ cotended that Rokeach Value Survey (RVS) and List of Values (LOV) are two most widely used instruments to measure personal values, and for values based segmentation $(13,14)$, however the researcher also included Values and Lifestyle (VALS) as it is also mentioned by Novak \& MacEvoy that VALS is also popular instrument used to measures personal values and for values based segmentation (14). One of the earliest and commonly used instruments in studies of values is Rokeach Value Survey (RVS). This instrument comprises of 2 sets of values, they are 18 Terminal values; A Comfortable Life, Equality, An Exciting Life, Family Security, Freedom, Health, Inner Harmony, Mature Love, National Security, Pleasure, Salvation, Self-Respect, A Sense of Accomplishment, Social Recognition, True Friendship, Wisdom, A World at Peace, A World of Beauty (15) In addition to 18 Instrumental values Ambitious, Broad-minded, Capable, Clean, Courageous, Forgiving, Helpful, Honest, Imaginative, Independent, Intellectual, Logical, Loving, Loyal, Obedient, Polite, Responsible, Self- controls (15). Those values are then ranked according to their importance to the respondent' life (11). Despite of its popularity as an instrument of personal values measurement the RVS is not without weaknesses, the relevance of values used in the RVS with respondent's daily life is questionable (16). Other issue is the number of values in Rokeach Value System which respondent should rank; the researcher argues that 18 instrumental values plus 18 terminal values in RVS are a large number for respondent to understand and rank one by one in short time, subsequently the answers might be less reliable thus reducing the effectiveness of the measurement. In 1983 Mitchell in SRI International developed values and Lifestlyles (VALS) and it was developed partly based on Maslow's Human needs hierarchy (17). VALS firstly tested in USA and comprises of nine groups of lifestyles namely Survivors, Sustainers, Belongers, Emulators, Achievers, I am me, Experiential, Societally conscious and integrated, these groups were identified through asking the respondents a series of 34 questions of various attitude statements and demographics variables (17). VALS instrument were used widely in the industry and for marketing practitioners, partly because it is considered more perspicuous and clear in portraying individuals in the groups. (17). However, VALS is rarely used in academic contexts $(18,17,14)$ which may show its lack of theoretical supports. The researcher argues that other issue on VALS is the large number of questions, which are more than 30 questions in VALS survey which a respondent should fill in/answer will likely to discourage or deter respondents from joining the survey especially in more than single variable research where the survey measure not only values but also other variables and subsequently adding to the already large number of VALS questions in the questionnaire.

The other instrument widely used to measure values is The List of Values (LOV) which was developed by researchers in the University of Michigan Survey Research Center (17). Kahle modified Rokeach Values Survey (RVS) 18 terminal values into a simpler 9 items subset. (19) The LOV consists of nine personal values, namely self-fulfillment, self-respect, sense of Accomplishment, being well respected, security, sense of belonging, warm relationship with others, fun and enjoyment in life, and excitement (8). To measure personal values using LOV respondent will be asked to rate all LOV's nine values based on its importance to respondents' daily life, afterward the respondent will be asked to rank one value, which considered as the most important in life by the respondent. (18) Fun and Enjoyment and Excitement values are tend to perceived the same by respondent, hence one them are sometimes collapsed in the questionnaire (18). The previous studies utilizing the LOV have three underlying dimensions: internal, external, and fun and enjoyment values $(20,18,17)$. Internal values represent the belief that personal values fulfillment can actually be controlled by one self or individual. These values are reflected in self-respect, self-fulfillment and sense of 
accomplishment. In the contrary external values, represent fulfillment that is beyond individual control, which are reflected in security, warm relationship with other, well respected and sense of belonging. (7). Fun and enjoyment on the other hand are believed to be a mixed of internal and external values as it is considered that one can have fun and enjoyment themselves or through social interaction (7). With a smaller number of values, which respondent should rank and rate, LOV offers a more effective way to measure values. This argument is further support by the subsequent studies, which concluded that LOV is more reliable with greater validity and offers higher parsimony level $(18,19)$. It also contended that LOV is easier to understand by respondent and easier to administrate and analyze by the researcher (18), Furthermore the LOV usability and validity in various contexts has been proved by (5) on organic food consumer, (8) in moviegoers' segmentation, etc.

\section{Destination Image}

Study on destination Image has been increasing in the last decade (21), This arguably because of its importance as a significant factor influencing decision to visit a destination (6) and its role as a key factor in promoting the destination (22) image give the potential tourist 'pre-taste' of the destination (23) There are more than 250 academic papers and articles are published since the 1970's discussing about destination image. (21). One definition from a psychologist point of view describes 'Imagery' as a Processing and storing multisensory information in working memory method (24). Many researches which uses the word destination image tend to define it loosely and not precise. $(25,24)$. However, in the literature the terms Destination Image among other is commonly defined as

"An attitudinal construct consisting of an individual's mental representation of knowledge (beliefs), feelings, and global impression about an object or destination " (6)

It is also indicated that destination image can be described as cognitive and affective factors that form attitudinal judgment towards a destination (6). Hence a positive image of a destination will make the destination stand out from the competitors and have a better chance of being selected as a holiday destination by tourists (1) In the literatures, researchers have different opinions regarding the process of destination image formation and factors, However, there is consensus that a destination image contains both cognitive component, which related to what a tourist has in mind about the destination tangible features, and an affective component, which related to the tourist feeling of the destination (26). An evaluation on both of those component resulted in the overall image of the destination whether it is positive or negative $(6,25)$. Despite of the lack of consensus among researcher regarding the impact of visitation on the destination image (25), (24) contended that visitation experience will modify the previous image held by the tourist. Further past studies in the literature indicated that tourist who has visited a destination tend to have more positive image of the destination compared to tourist who has never been there. $(27,28)$ In the contrary another study conducted by (23) indicated that tourist who never visit a destination tend to have better perception towards the destination image compared to tourist who have been there previously. There are considerable number of studies available in the literature related to destination image, however only few empirical researches focused on the destination image formation, especially with the absence of actual visitation (6)

\begin{tabular}{|c|c|c|}
\hline $\begin{array}{l}\text { Personal Factor } \\
\text { - Psychological } \\
\text { - Values } \\
\text { - Motivations } \\
\text { - Personality } \\
\text { - Social } \\
\text { - Age } \\
\text { - Education } \\
\text { - Marital } \\
\text { Status } \\
\text { - Others }\end{array}$ & $\begin{array}{l}\begin{array}{l}\text { Destination } \\
\text { Image }\end{array} \\
\text { - Perceptual/ } \\
\text { Cognitive } \\
\text { - Affective } \\
\text { - Global }\end{array}$ & $\begin{array}{l}\text { Stimulus Factors } \\
\text { - Information } \\
\text { Sources } \\
\text { - Amount } \\
\text { - Type } \\
\text { - Previous } \\
\text { Experience } \\
\text { - Distribution }\end{array}$ \\
\hline
\end{tabular}

Fig. 1. General Framework of Destinaton Image Formulation (6)

From the figure 1 above we can argue that Both Stimulus \& Personal Factors or Tourist Characteristics formed a destination image, where Personal factors represent 'Push factors' (29) while destination touristic attributes which are projected in stimulus factor information sources are the 'Pull factor' of the tourist travel (29). In relation with destination image formation process many authors proposed to interpret image before visiting the destination and image build after visiting the destination (1)

Even before visiting the destination, visitor or potential visitor already have an image of the destination in their mind $(1,24)$ however this image is largely subjective because it's mostly based on information and experiences tourist have on various other destinations (3). Despite of its subjective nature researchers believe that pre-trip image formation is the most important period for tourist destination selection process (6) therefore studying the destination image in this stage is crucial. Findings from past studies has shown that in the absence of actual visitation psychological aspects including values has a significant effect in forming destination image. (3) These values serve as filter for the information received regarding the destination (30). Another study also identify tourist motivations, socio-demographics and information from various sources as major influential factor in destination image formation in the absence of actual visitation (6). The same author also contented that Information sources affect only perceptual/cognitive evaluation aspect, while Socio-psychological motivations affect 
only affective evaluation. On the other hand sociodemographic factors affect both perceptual/cognitive and Affective evaluation where subsequently a combination of cognitive and affective evaluation will form the overall image of the destination. As discussed before that various sources of information are important factor in the destination image formation process. (1) defines image of the destination in potential visitors' mind prior or in absence of actual visitation as a secondary image.

After experiencing or visiting the destination, previsit image (secondary image) whom a visitor had previously will be compared to the actual condition of the destination. This in turn will form Post-visitation image or described as Primary image by (1) Indeed primary and secondary images may differ (25) with the former being more realistic and complex than the later (25)

\subsection{Measurement of Destination Image}

From the past studies on destination image available in the literature, the researcher found that there are two basic approaches to measure image, which are structured and unstructured methods. Most researchers using structured methodology in measuring the destination image, by incorporated specific and common destination attributes into standardized instrument, $(24,29,31)$. The reason behind this trend is that structured methodologies usually use a standardized scale, which is easier to administer and analyze (24). Most past studies also attributes focused and put little attention towards the holistic image of the destination (24) however, a justified theory to replace the multi-variable models of measurement is not yet available $(31,24)$.

\begin{tabular}{|l|l|}
\hline Functional & Various Activities \\
Landscape \\
Nature \\
Cultural Attractions \\
Nightlife \& Entertainment \\
Shopping Facilities \\
Information Available \\
Sports Facilities \\
Transportation \\
Accommodation \\
Gastronomy \\
Price, Value, Cost \\
Climate \\
Relaxation \\
Safety \\
Social Interaction \\
Service Quality \\
Environment \\
Infrastructure \\
\hline
\end{tabular}

Figure 2. Destination Image Attributes (32)

Figure 2 above describes some destination attributes from functional (tangible) attributes to more Psychological (intangible) attributes that are commonly used to measure image of a tourist destination in the past studies. Taking into account the advantages and disadvantages aspects, researcher contend that until a new justified method is developed, the most appropriate way to measure a destination image is by incorporate common attributes and specific attributes of a destination and also incorporate holistic image measurement into the structured instrument for respondent.

\section{RESEARCh QUESTION AND HypotheSES}

After reviewing extensive literatures on Personal Values, Destination Image and the importance of this research is justified whereas some theory already incorporated 'Values' in the Destination image formation. However very few past studies in the literatures have tried to evaluate the significance of personal values on visitor/potential visitor perception of Destination Image. Therefore, several Research questions and hypotheses have been subsequently developed for this research.

$\mathrm{H}_{1}$ : Potential visitor and visitor perception towards the destination image of Palabuhan Ratu are significantly different

$\mathrm{H}_{12}$ : Personal Values is significantly affect Potential visitor's perception of Palabuhan Ratu Destination Image

$\mathrm{H}_{1_{-} 3}$ : Personal Values is significantly affect visitor's perception of Palabuhan Ratu Destination Image.

\section{Methodology}

This research adopted deductive approach, which used existing empirical and theoretical knowledge of the subject as commencement point, and then tested the theory through hypotheses which are logical consequences of the theory (33) therefore an extensive literature study on personal values, destination image and the connection between them were carried out in this research. Then several hypotheses were developed and tested. In deductive approach, the theory and hypotheses tested may be proved or confirmed by the findings in the end of the research. However if the research findings show contrasting evidences the tested theory may need some modifications or even replaced with new theory in some extreme cases (33). This research adopted survey approach instead of interview because it was deemed as better way to reach a broad range of respondents, represent larger population and produce a quantifiable empirical data (34). Surveys also used in many previous studies of destination image in the literatures (21) and also personal values studies such as on Organic consumer personal values (5) and Values segmentation of movie goers (8), etc.

A quantitative approach was adopted in this research because it has been the most used approach in previous studies of destination image (24) which can be seen as a sign that this approach was appropriate and 
widely acceptable for these subjects. In the other hand qualitative approach for this research was seen as less inappropriate because of several reasons; it is time consuming, and less representative of the target population due to its very small sample size (35). The target population was the main visitors and potential visitor of Palabuhan Ratu as explained by Palabuhan Ratu Tourism Authority. They were people under 25 years of age and reside in surrounding cities of Palabuhan Ratu such as Jakarta, Bandung, Bogor and Sukabumi. However as there was no data of actual number of visitor to Palabuhan Ratu available, and the exact number of people aged 18-25 years old in Palabuhan Ratu surrounding cities were very large, researcher used the recent estimation from the Palabuhan Ratu and Sukabumi regency local tourism authority, which estimated the number of visitors to Palabuhan Ratu in 2012 was around 1.4 million people as the size of the target population. From that population size a sample size of minimum 150 is seen as ideal for this research, with goal of representativeness in mind, samples were taken from Sekolah Tinggi Pariwisata Bandung students and alumni who offers better access and response rate and also the demographic characteristics of the students especially age and domicile wise were suitable with the majority of visitor and potential visitor demographic profile of Palabuhan Ratu. By the end of the survey 154 questionnaires were successfully completed

TABLE I

Tests of Between-Subjects Effects Dependent Variable: IMAGE PERCEPTION

\begin{tabular}{|l|l|l|l|l|l|l|}
\hline & $\begin{array}{l}\text { Type III } \\
\text { Sum of } \\
\text { Squares }\end{array}$ & df & $\begin{array}{l}\text { Mean } \\
\text { Square }\end{array}$ & F & Sig. & $\begin{array}{l}\text { Partial } \\
\text { Eta } \\
\text { Square } \\
\text { d }\end{array}$ \\
\hline $\begin{array}{l}\text { Corrected } \\
\text { Model }\end{array}$ & $5.335^{\mathrm{a}}$ & 3 & 1.778 & 8.396 & .000 & .144 \\
Intercept & 22.341 & 1 & 22.341 & 105.47 & .000 & .413 \\
Visitation \\
Status
\end{tabular}

A mix of face to face survey and self-administered survey were used as the measuring instrument in this research. The former were mainly used for surveys in Bandung as face to face surveys offered some higher response rate, allowed for clarification, and opportunity for the researcher to build trust and motivated the respondents (34) while the later were mainly used for surveys outside Bandung as it offered wider geographical range and allowed the respondents to answer in their own preferred time (34). The questionnaire was developed by the researchers into several sections, the first section was intended to identify respondent demographic aspects and if the respondent had known Palabuhan Ratu and visited the place before. In the following sections of the questionnaire questions on visitors and potential visitors perceptions of Palabuhan Ratu based on Palabuhan Ratu destination attributes which used by researchers in previous studies on Destination image as described by (24) and study carried out by (32) on Pre and Post Trip destination image variation, The last section was questions to determine the personal values aspect of the respondent using List of Values (LOV) as it is considered as easier to understand by respondent and easier to administrate and analyzed by the researcher. (18). It is also offered greater reliability, validity and parsimony level $(18,19)$

\section{Results AND Hypotheses Testing}

\subsection{Respondent Profiles}

There were only slight difference in number of male and female in the sample, with $53 \%$ of the respondents identify themselves as female and $47 \%$ identify themselves as male. The majority of respondents $(73 \%)$ were aged $18-21$ years old while the rest $(27 \%)$ were aged $22-25$ years old. (79\%) of the respondents were Sekolah Tinggi Pariwisata Bandung students and Alumni, while $8 \%$ were from Jakarta and $12 \%$ from Bogor. Subsequently $86 \%$ of the respondents were students with primary or secondary school as their last education level.

\subsection{Visitor and Potential Visitor Perception}

The respondents were $68 \%$ visitors and $32 \%$ potential visitors. (47\%) visited Palabuhan Ratu more than two years ago, around $28 \%$ visited Palabuhan Ratu less than a year ago and around $25 \%$ visited Palabuhan Ratu sometimes during 1-2 years ago. In order to investigate whether potential visitors and visitors showed statistically significant difference in their perception on Palabuhan Ratu destination image, subsequently test the Hypothesis 1, the researcheranalyzed respondents' visitation status and perception using SPSS.

Through univariate analysis of variance performed in the SPSS, see table 1, it was found out that visitation status did not affect the perception of image, and there was no significant difference between potential visitor and visitor perception on destination image of Palabuhan Ratu (p 0.645>0.05) Hence, hypothesis 1 was rejected.

\subsection{Destination Attributes}

Most respondents consider low cost $(16 \%)$, great beaches (15\%) and good accessibility (14\%) as the main elements or attributes that attract them to a destination. The next significant elements were the friendliness of local people $(10 \%)$ while Choice of Activities, Safety and Weather were each chosen by $9 \%$ of the respondents. In contrast, nightlife or entertainment was the least chosen element with only 
(3\%) of the respondents considered this element as important. The researcher found that the perception of respondents towards Palabuhan Ratu image especially on cost, accessibility and beaches attributes that were considered as main elements or attributes by respondents were generally positive. $(77.3 \%)$ of the respondent were either strongly agree or agree with the statement that Palabuhan Ratu offered low cost holiday option.(62.4\%) of the respondent either strongly agree or agree that Palabuhan Ratu has great beaches, and lastly $(49.4 \%)$ of the respondents either strongly agree or agree that Palabuhan Ratu was easy to reach. This result indicates that most of the respondents emphasize on directly observable tangible attributes represented by beaches and cost/price level compared to intangible attributes to determine which destination is attractive.

From 10 destination attributes of Palabuhan Ratu, respondents saw Night Life and Entertainment least positively; only (17\%) of the respondents were strongly agree or agree to the statement that Palabuhan Ratu has a good nightlife and entertainment. Safety and choice of activities were the next two attributes with the lowest level of perception with only $(43 \%)$ and $(40 \%)$ of the respondents were strongly agree or agree with the statements that Palabuhan Ratu is safe for tourist and offered various choices of activities. However, as discussed before nightlife was also considered as least important elements / attributes of destination by the respondents. Hence, the low perceived image of nightlife in Palabuhan Ratu is unlikely to affect the overall image of Palabuhan Ratu significantly.

\subsection{Personal Values Ranking and Rating}

The frequency analysis indicated that Sense of Belonging was most frequently chosen values with $29.9 \%$ respondents. Meanwhile Warm Relationship with others (25.3\%) and Excitement (14.9) were on 2nd and 3rd position respectively. This finding is a further indication of the tendency among respondents to put more importance on external values that are fulfilled through interaction with other people and Values such as fun and enjoyment and excitement, which offers mixed fulfillment through social interaction with others or by themselves. It should be also noted that were no respondents who put self-respect and Security as their most important Personal values in their daily life.

\subsection{Personal Values and Perception of Destination Image}

To analyze the correlation and effect of personal values on destination image and test hypothesis 2 and 3 , a simple regression and univariate analysis of variance were performed by the researcher. The data used for these analytical purposes were the overall image from the overall means of each destination attributes scores. For personal values, the mean of overall importance score of the LOV 9 values were used as analytical data.

TABLE II CORRELATIONS

\begin{tabular}{|ll|r|r|}
\hline & & \multicolumn{1}{|c|}{ Image } & \multicolumn{1}{c|}{ Value } \\
\hline $\begin{array}{l}\text { Pearson } \\
\text { Correlation }\end{array}$ & Image & 1.000 & .266 \\
& Value & .266 & 1.000 \\
\hline Sig. (1-tailed) & Image &. & .000 \\
& Value & .000 &. \\
\hline $\mathrm{N}$ & Image & 154 & 154 \\
& Value & 154 & 154 \\
\hline
\end{tabular}

TABLE III Model Summary

\begin{tabular}{|l|r|r|r|c|}
\hline Model & $\mathrm{R}$ & \multicolumn{1}{|c|}{ R Square } & $\begin{array}{c}\text { Adjusted R } \\
\text { Square }\end{array}$ & $\begin{array}{c}\text { Std. Error of the } \\
\text { Estimate }\end{array}$ \\
\hline 1 & $.266^{\mathrm{a}}$ & .071 & .065 & .41611 \\
\hline
\end{tabular}

TABLE IV Coefficients ${ }^{\mathrm{a}}$

\begin{tabular}{|c|c|c|c|c|c|c|}
\hline \multirow{2}{*}{\multicolumn{2}{|c|}{ Model }} & \multicolumn{2}{|c|}{$\begin{array}{c}\text { Unstandardized } \\
\text { Coefficients }\end{array}$} & $\begin{array}{l}\text { Standardized } \\
\text { Coefficients }\end{array}$ & \multirow{3}{*}{$\begin{array}{c}\mathrm{t} \\
8.507\end{array}$} & \multirow{3}{*}{$\begin{array}{l}\text { Sig. } \\
.000\end{array}$} \\
\hline & & B & Std. Error & Beta & & \\
\hline \multirow[t]{2}{*}{1} & (Constant) & 2.477 & .291 & & & \\
\hline & Value & .134 & .039 & .266 & 3.403 & .001 \\
\hline
\end{tabular}

Table II, III and IV above showed the regression analysis on Destination image and Personal Values results. There was positive and significant correlation between Personal Values and Destination Image perception of potential visitor and visitor. The result of analysis showed that Personal Values significantly affect destination image with the contribution of $7.1 \%$; $\mathrm{R}^{2}=0.071$, Beta $=0.266$ and $\mathrm{p}<0.05$. 


\section{TABLE V CORRELATIONS}

Univariate analysis of Variant on Personal Values and Destination Image Perception Tests of Between-Subjects Effects

\begin{tabular}{|c|c|c|c|c|c|c|}
\hline Source & $\begin{array}{l}\text { Type III } \\
\text { Sum of } \\
\text { Squares }\end{array}$ & $\mathrm{df}$ & $\begin{array}{c}\text { Mean } \\
\text { Square }\end{array}$ & $\mathrm{F}$ & Sig. & $\begin{array}{l}\text { Partial } \\
\text { Eta } \\
\text { Square } \\
\text { d }\end{array}$ \\
\hline $\begin{array}{l}\text { Corrected } \\
\text { Model }\end{array}$ & $5.335^{\mathrm{a}}$ & 3 & 1.778 & 8.396 & .000 & .144 \\
\hline Intercept & 22.341 & 1 & 22.341 & $\begin{array}{r}105.47 \\
3\end{array}$ & .000 & .413 \\
\hline $\begin{array}{l}\text { Visitation } \\
\text { Status }\end{array}$ & .045 & 1 & .045 & .214 & .645 & .001 \\
\hline Values & 1.834 & 1 & 1.834 & 8.657 & .004 & .055 \\
\hline $\begin{array}{l}\text { Visitation } \\
\text { Status * } \\
\text { Values }\end{array}$ & .213 & 1 & .213 & 1.005 & .318 & .007 \\
\hline Error & 31.773 & 150 & .212 & & & \\
\hline Total & 1836.049 & 154 & & & & \\
\hline $\begin{array}{l}\text { Corrected } \\
\text { Total }\end{array}$ & 37.108 & 153 & & & & \\
\hline
\end{tabular}

Note: Level of significance $\mathrm{p}<0.05$

Table $\mathrm{V}$ above showed that there was no significant correlation between visitation status and personal values. ( $p>0.05)$. Hence, it can be concluded that personal values equally affect the potential visitor and visitor image perception of Palabuhan Ratu. From discussion above the significant effect of Personal Values on the Image perception of Non-visitor and visitor of Palabuhan Ratu were confirmed. Subsequently hypothesis 2 and 3 were accepted.

\section{DISCUSSION}

The result from data analysis indicated that overall perception toward Palabuhan Ratu image, as tourist destination was positive. However, there was no significant difference in the perception of potential visitor a visitor toward Palabuhan Ratu image as tourist destination, which means hypothesis 1 was rejected. This finding was contrast with studies conducted by $(27,28)$ that found a significant difference in perceptions between visitor and non-visitor. However this finding supported the lack of consensus among researchers regarding the impact of visitation toward perception of image (25)

The researcher argued that the secondary image in the potential visitor mind before the visitation was actually similar to the reality hence an actual visitation did not significantly affect the primary or total image perception.

The next important finding from this survey was the effect of personal values on perception of destination image was confirmed. Through regression analysis in SPSS a significant and positive correlation and significant influence of personal values on perception of
Palabuhan Ratu image was statistically proven. This finding was in line with previous studies which were conducted by $(6,9)$ which stated that Values affect perception and image.

This finding did not support the argument that pre and post perception of image may vary significantly, which put forth by $(23,27,28)$. In the contrary this finding supported the lack of consensus among the researcher on the impact of visitation on the destination image (25).

\section{CONCLUSION}

The aim of this research was to study the effect of personal values on potential visitor and visitor perception towards Palabuhan Ratu image as tourist destination. Several hypotheses were developed to achieve the aim. Hypothesis 1 stated that there were statistically significant difference between potential visitor and visitor perception on Palabuhan Ratu image as a tourist destination. This hypothesis was based on the previous research conducted by $(27,28)$ which showed differences perceptions between non visitor and visitor. The second and third hypotheses about the effect of personal values on potential visitor and visitor were based on the arguments from $(6,9)$ which contended that personal values affect perception and image.

This research adopted quantitative method, with a positivist stance to ensure its objectivity. Samples were taken from Bandung, Bogor and Jakarta through nonrandom sampling technique. Although considered as less representative compared to random sampling technique, non-random sample can still provide usefull insight to the target population. The choice of samples derived from non-random sampling technique was further supported by O'Leary (34) who contended that non random sampling was used strategically to match the target population characteristics. Students and Alumni of Sekolah Tinggi Pariwisata Bandung was strategically chosen by the researcher as the main sample population. Students and alumni of Sekolah Tinggi Pariwisata Bandung was seen ideal by the researcher because they matched the main population characteristics as described by Palabuhan Ratu tourism authority. However to enhance the representativeness level, people matched the population profile from Bogor and Jakarta were also used as samples. Survey using questionnaire was used as primary instrument for collecting data from sample. The questions in the questionnaire were developed from previous studies on Destination Image and Personal Values. The Data from the questionnaires were collected and then analyzed using SPSS.

In summary, the main contribution of this research to the literature was the empirical data resulted from the analysis, which confirmed the significant effect of personal values towards perception of destination image especially in tourism context. Before this research, there 
were very limited previous researches in the literatures that specifically studied personal values effect on Destination image perception. Other contribution from this research was the empirical data from the research that defy the previous arguments from $(27,28)$ regarding the difference of image perception between visitor and non-visitor, the findings of this study have made an important contribution to existing literature and have highlighted some important market implications.

The research practical contributions were mainly suitable for the tourism authority of Palabuhan Ratu. The research provides useful insight to the target market population, mostly in terms of their personal values and their perception towards Palabuhan Ratu Image as tourist destination. This research had identified and highlighted several important finding such as destination attributes, which were considered important by potential visitor and visitor subsequently most positively perceived attributes was also described in the findings. In the contrary, least important and least positively perceived attributes were also explained. The last were the most important source of information used by potential market of Palabuhan Ratu was also indicated.

All of those information and data can be used to enhance the visitor profile data available in the tourism authority. Further market segmentation or product development can also benefit from the data and information provided by this research.

\section{REFERENCES}

[1] Lopes, S. D. (2011). Destination image: Origins, Developments and Implications. PASOS. Revista de Turismo y Patrimonio Cultural, 9(2), 305-311.

[2] Gallarza, M. G., Saura, I. G., \& Garcia, H. C. (2002). Destination Image, Towards coneptual Frameworks. Annals of Tourism Research, 29, 56-78.

[3] San Martin, H., \& Rodriguez del Bosco, I. A. (2008). Exploring the cognitive-affective nature of destination image and the role of psychological factors in its formation. Tourism Management, 29, 263-277.

[4] Kamakura, W. A., \& Thomas, N. P. (1992). Value-system segmentation:Exploring the meaning of LOV. Journal of Consumer Research, 19, 119-132.

[5] Chryssohoidis, G. M., \& Krystallis, A. (2005). Organic consumers' personal values research: Testing and validating the list of values (LOV) scale and implementing a value-based segmentation task. Food Quality and Preference, 16, 585-599.

[6] Baloglu, S., \& McCleary, K. (1999). A Model of Destination Image Formation. Annals of Tourism Research, 26, 868-897.

[7] Februadi, A. (2012). The Effect of Personal Values On Consumer Perception of Country Image and Destination Image . Asian Tourism Forum. Bandung: Sekolah Tinggi Pariwisata Bandung

[8] Marchand, J., \& Khallaayoune, Z. (2010). LOV' and the big screen: A value-system segmentation of movie goers. Journal of Targeting, Measurement and Analysis for Marketing , 18, 177188.

[9] Vecchione, M., Caprara, G., Schoen, H., Castro, J. L., \& Schwartz, S. H. (2012). The role of personal values and basic traits in perceptions of the consequences of immigration: A three nation study. British Journal of Psychology, 103, 359-377.

[10] Kamakura, W. A., \& Novak, T. P. (1992). Value-system segmentation:Exploring the meaning of LOV. Journal of Consumer Research, 19, 119-132

[11] Kamakura, W. A., \& Mazzon, J. A. (1991). Value Segmentation: A Model for the Measurement of Values and Value Systems. JOURNAL OF CONSUMER RESEARCH, 15, 208-218.

[12] LI, M., \& Cai, L. A. (2012). The Effects of Personal Values on Travel Motivation and Behavioral Intention. Journal of Travel Research, 51(4), 473-487.

[13] Dalen, E. (1989). 'Trends In Customer Demand: Research Into Values And Consumer Trends In Norway'. Tourism Management, 10(3), 183-186.

[14] Novak, T. P., \& MacEvoy, B. (1990). On Comparing Alternative Segmentation Schemes: The List of Values (LOV) and Values and Life Styles (VALS). JOURNAL OF CONSUMER RESEARCH, 17, 105-109.

[15] Universitas Hasanuddin. (n.d.). Rokeach Value Survey. Retrieved December 3, 2013, from Universitas Hasanuddin website: www.unhas.ac.id/ rhiza/arsip

[16] Clawson, J. C., \& Vinson, D. E. (1978). Human Values: A Historical And Interdisciplinary Analysis. Advances In Consumer Research, 5(1), 396-402.

[17] Kahle, L. R., Beatty, S. E., \& Homer, P. (1986). Alternative Measurement Approaches to Consumer Values: The List of Values (LOV) and Values and Life Style (VALS). Journal of Consumer Research, 13, 405-409.

[18] Kahle, L. R., \& Kennedy, P. (1988). Using The List of Values (LOV) To understand Consumer. Journal of Services Marketing, 2(4), 49-56

[19] McIntyre, McIntyre, R. P., Claxton, R. P., \& Jones, D. B. (1994). Empirical Relationships Between Cognitive Style and LOV: Implications for Values and Value Systems. Advances in Consumer Research, 21, 141-146.

[20] Batra, R., Homer, P. M., \& Kahle, L. R. (2001). Values, Susceptibility to Normative Influence, and Attribute Importance Weights: A Nomological Analysis. Journal of Consumer Psychology, 11(2), 115-128.

[21] Pike, S. (2007). Destination Image Literature 2001 to 2007. Acta Turistica, 107-125.

[22] Ramkisson, H., Uysal, M., \& Brown, K. (2011). Relationship Between Destination Image and Behavioral Intentions of Tourists to Consume Cultural Attractions. Journal of Hospitality Marketing \& Management, 20, 575-595.

[23] Fakeye, P. C., \& Crompton, J. L. (1991). Image Differences between Prospective, First-Time, and Repeat Visitors to the Lower Rio Grande Valley. Journal of Travel Research, 30(10), 10-16.

[24] Echtner, C. M., \& Ritchie, J. B. (2003). The Meaning and Measurement of Destination Image. The Journal of Tourism Studies, 14(1), 37-48.

[25] Beerli, A., \& Martin, J. D. (2004). Factors Influencing Destination Image. Annals of Tourism Research, Vol. 31, No. 3, pp. 657-681, 2004, 31(3), 657-681.

[26] Pan, B., \& Li, X. (2011). The Long Tail of Destination Image and Online Marketing. Annals of Tourism Research, 38(1), 132152.

[27] Hughes, H. L. (2008). Visitors and Non-visitors Destination Image: the influence of political instability. Tourism: Preliminary Communication, 56(1), 59-74.

[28] Kim, S. S., McKercher, B., \& Lee, H. (2009). Tracking Tourism Destination Image Perception. Annals of Tourism Research, 36, 715-718.

[29] Kim, S. S., \& Lee, C.-K. (2002). Push and Pull relationship. Annals of Tourism Research, 29(1), 257-260. 
[30] Moutinho, L. (1987). Consumer Behaviour in Tourism. European Journal of Marketing, 21(10), 3-44.

[31] Pike, S. (2002). Destination image analysis - a review of 142 papers from 1973 - 2000. Tourism Management , 23, 541-549.

[32] Yilmaz, Y., Yilmaz, Y., Icigen, E. T., Ekin, Y., \& Utku, B. D. (2009). Destination Image: A Comparative Study on Pre and Post Trip Image Variations. Journal of Hospitality Marketing \& Management, 18, 461-479.

[33] Brotherton, B. (2008). Researching Hospitality \& Tourism. London: Sage.

[34] O'Leary, Z. (2010). The Essential Guide To Doing Your Research Project. London: Sage.

[35] Denscombe, M. (2007). The Good Research Guide. London: Open University Press. 